\title{
HUBUNGAN AKTIVITAS BEROLAHRAGA DENGAN TOLERANSI STRES PADA MAHASISWA LAKI-LAKI FAKULTAS KEDOKTERAN
}

\author{
Prida Harkina $^{1}$, Vira Sandayanti ${ }^{2}$, Ahmad Yunus Feryaldi $^{3}$ \\ ${ }^{12}$ Program Studi Psikologi, FK Universitas Malahayati, Bandar Lampung. Email: \\ ${ }^{3}$ Program Studi Pendidikan Dokter, FK Universitas Malahayati, Bandar Lampung \\ prida@malahayati.ac.id
}

\begin{abstract}
Stres was a condition that was close to our daily life, including to male students of medical faculty. Curriculum methods, large and integrated study materials demand, also long-term study times, could be enough stresors. Exercising has many benefits, not only physically but also to practice our response to stres condition. This study aimed to find relationship between exercise activities with stres tolerance, with hypothesis there were relationship between exercise activities with stres tolerance on male medical faculty students. Subjects on this study were 88 male students from medical faculty of Malahayati University. This study was an observation analytic study with cross sectional approach. Result data analyzed used Mann Whitney Test, with $p$ value $<0,05$. The result of bivariate test using Mann Whitney shown that there was relationship of exercise activity with stres tolerance with $p=0,000(p>0,05)$.
\end{abstract}

Keywords:, Medical Faculty Students, Exercising Stres, Tolerance.

\begin{abstract}
ABSTRAK
Stres adalah kondisi yang dekat dengan kehidupan sehari-hari, tidak terkecuali pada mahasiswa lakilaki di Fakultas Kedokteran. Metode pembelajaran, tuntutan penguasaan materi yang luas dan terintegrasi, serta waktu pendidikan yang cukup lama, cukup dapat menjadi penyebab stres pada mahasiswa fakultas kedokteran. Olahraga bermanfaat tidak hanya untuk kesehatan fisik tetapi juga bermanfaat dalam melatih respon terhadap kondisi stres. Penelitian ini bertujuan untuk menemukan apakah terdapat hubungan antara aktivitas berolahraga dengan toleransi stres pada mahasiswa lakilaki Fakultas Kedokteran, dengan hipotesis bahwa terdapat hubungan antara aktivitas berolahraga dengan toleransi stres pada mahasiswa laki-laki Fakultas Kedokteran. Subjek penelitian ini adalah mahasiswa laki-laki Fakultas Kedokteran Universitas Malahahayati Bandar Lampung sejumlah 88 orang. Penelitian ini merupakan penelitian observasi analitik dengan pendekatan cross sectional. Analisa data hasil penelitian menggunakan korelasi Mann Whitney, dengan $p$ value $<0,05$. Hasil uji bivariat dengan nilai $p$ adalah $0,000(\mathrm{p}>0,05)$ dapat disimpulkan bahwa terdapat hubungan aktivitas olahraga dengan toleransi stres.
\end{abstract}

Kata Kunci: Mahasiswa Kedokteran, Olahraga, Toleransi Stres 


\section{PENDAHULUAN}

Stres adalah suatu kondisi yang dinamis, dimana individu dihadapkan pada adanya sebuah peluang, batasan, dan tuntutan dari sesuatu yang sangat dia inginkan dan dimana hasil akhirnya adalah sesuatu yang dirasa penting namun tidak yakin dapat dicapai (Robbins' 2001). Kondisi stres juga dapat menimbulkan perubahan fisik (biokimia, neurohormon, dan imunitas) serta psikologis (kognitif dan perilaku) pada individu yang mengalaminya (Robbins' 2001). Jika individu tidak dapat menanggulangi stres yang dialaminya, maka stres akan menjadi kondisi yang berkelanjutan dan dapat memiliki dampak yang buruk, seperti timbulnya masalah gangguan psikologis, berupa kecemasan berlebihan, emosi yang labil, bahkan pada kasus lain ditemukan stres menjadi awal munculnya gangguan depresi yang kemudian mengarah sebagai penyebab banyaknya tindakan bunuh diri (Sarason, 1978). Selain gangguan psikologis, stres juga dapat menyebabkan gangguan fisik, berupa beberapa penyakit kronis seperti gangguan kardio-vaskular, muskuloskeletal, gastrointestinal, kanker serta penurunan imunitas (Shah dkk, 2010).

Stres merupakan suatu siklus berkelanjutan yang memiliki suatu mekanisme umpan balik (Weinberg, 2003). Mekanisme umpan balik tersebut memerlukan kemampuan adaptasi atau toleransi yang baik dari diri individu terhadap situasi stres yang dihadapinya. Seseorang dengan toleransi stres yang tinggi akan dapat bertahan dan beradaptasi dengan baik terhadap berbagai stresor (penyebab stres). Sebaliknya, seseorang dengan toleransi stres yang rendah tidak mampu beradaptasi terhadap stres dengan baik sehingga rentan mengalami distres (Semiun, 2006).

Mahasiswa Fakutas Kedokteran adalah salah satu contoh individu yang dekat dengan kondisi stres. Stres yang dialami oleh mahasiswa kedokteran dapat disebabkan oleh berbagai macam stresor, seperti stresor psikososial, stresor yang berhubungan dengan kesehatan dan stresor akademik (Christyanti dkk, 2012). Stresor akademik meliputi metode pembelajaran, tuntutan penguasaan materi yang luas dan terintegrasi serta waktu pendidikan yang cukup lama. Metode pembelajaran menuntut mahasiswa untuk mampu mengatasi masalah secara mandiri. Tuntutan terhadap penguasaan materi 
membuat mahasiswa menghabiskan sebagian besar waktunya untuk belajar sehingga tidak memiliki banyak kesempatan untuk berinteraksi serta berhubungan sosial dengan teman - teman dan masyarakat diluar lingkungan belajarnya. Tuntutan tersebut menimbulkan stres psikologis dengan tingkatan yang bervariasi yaitu dari stres ringan, sedang, berat, hingga kondisi burnout, yang banyak ditemukan pada mahasiswa kedokteran (Sherina, 2003).

Penelitian lain yang dilakukan di berbagai negara juga menunjukkan bahwa mahasiswa fakultas kedokteran memiliki prevalansi stres yang lebih tinggi di bandingkan dengan mahasiswa di fakultas lain. Sebagai contoh, penelitian yang dilakukan di Adelaide (Leahy dkk, 2010) menunjukkan 38,2\% mahasiswa fakultas teknik mengalami stres, sementara penelitian yang dilakukan pada mahasiswa fakultas kedokteran di tempat uang sama menunjukkan hasil yang lebih tinggi. Penelitian lainnya dilakukan di salah satu perguruan tinggi di Malaysia terhadap seluruh mahasiswa fakultas kedokteran. Hasil penelitian menyebutkan bahwa sebesar 41.9\% mahasiswa fakultas kedokteran ditemukan mengalami stres sangat tinggi yaitu sekitar 73\% dan 61.4\% (Shah dkk (2010); Sherina, 2003).

Banyak upaya dapat dilakukan untuk mencegah mahasiswa mengalami stres, salah satunya melalui olahraga. Dari beberapa hasil penelitian yang pernah dilakukan sebelumnya, disebutkan bahwa olahraga yang dilakukan secara rutin dapat memberikan manfaat, bukan hanya untuk kesehatan fisik tetapi juga bermanfaat untuk kesehatan mental dan melatih adaptasi terhadap kondisi stres (Raglin \& Wilson, 2007). Sebagai contoh, penelitian yang dilakukan di Finlandia menunjukkan bahwa olahraga memiliki dampak positif terhadap 48.92\% responden, berupa penurunan depresi, emosi dan stres psikologis (Hassmen, 2000). Sementara penelitian lain di Jerman menunjukkan hasil bahwa $63.82 \%$ responden wanita yang aktif berolahraga memperlihatkan penurunan reaksi stres yang lebih baik dibandingkan dengan yang tidak pernah berolahraga (Klaperski dkk, 2012).

Selain itu, berdasarkan hasil penelitian yang dilakukan di Pakistan ditemukan bahwa terdapat perbedaan prevalensi stres yang dialami mahasiswa laki-laki dengan mahasiswa perempuan. Mahasiswa laki-laki memiliki prevalensi stres yang jauh lebih rendah (sebesar 32.92\%) dibandingkan 
mahasiswa perempuan (sebesar 67.08\%), yang disebabkan berbagai macam faktor seperti hormonal dan pola hidup yang berbeda di antara keduanya (Shah, 2010). Berdasarkan latar belakang di atas, maka peneliti tertarik untuk meneliti tentang apakah terdapat hubungan antara kegiatan berolahraga dengan toleransi stres pada mahasiswa laki-laki di Fakultas Kedokteran Universitas Malahayati angkatan 2014.

Tujuan umum dari penelitian ini adalah untuk membuktikan apakah terdapat hubungan antara kegiatan berolahraga dengan toleransi stres pada mahasiswa laki-laki di Fakultas Kedokteran Universitas Malahayati angkatan 2014. Sementara tujuan khususnya adalah mengetahui persentase jumlah mahasiswa laki-laki angkatan 2014 FK-UNMAL yang berolahraga dan tidak berolahraga, serta mengetahui persentase jumlah mahasiswa laki-laki angkatan 2014 FK-UNMAL dilihat dari tingkat toleransi stres mereka, apakah berada dalam tingkat rendah, sedang, ataukah tinggi.

\section{METODE PENELITIAN}

Penelitian ini memiliki dua variabel, yaitu "Aktivitas Berolahraga” sebagai variabel bebas atau independent variable dan "Toleransi Stres" sebagai variabel terikat atau dependent variable. Penelitian ini merupakan penelitian kuantitatif dengan design penelitian observational analitik, dan rancangan yang digunakan adalah rancangan penelitian cross sectional. Teknik pengambil sampel menggunakan teknik total sampling, dimana jumlah sampel adalah seluruh jumlah populasi yang ada. Dari sana didapatkan sampel sebanyak 88 mahasiswa laki-laki Fakultas Kedokteran Universitas Malahayati angkatan 2014.

Data penelitian didapatkan dengan melakukan wawancara mendalam untuk mendapatkan data anamnesa mengenai kegiatan berolahraga pada mahasiswa laki-laki, serta memberikan Inventory for Measuring Stres Tolerance (IMST) pada masing-masing subjek untuk mendapatkan data mengenai toleransi stres pada mahasiswa laki-laki. Setelah data terkumpul, lalu dilakukan analisa data dengan menggunakan analisa bivariat melalui uji Chi-Square $\left(X^{2}\right)$ for Trend dikarenakan disini peneliti ingin 
melihat trend dari toleransi stres (tinggi, sedang, rendah) pada mahasiswa laki-laki FK-UNMAL. Syarat uji Chi-square for trend adalah sel yang mempunyai nilai expected kurang dari 5 maksimal $20 \%$ dari jumlah sel apabila bentuk tabel $2 \times 3$, jika paling tidak ada dua sel yang mempunyai nilai expected kurang dari 5 maka di gunakan uji Mann-Whitney karena tujuanya untuk melihat trend dan tabel 2x3 (Uji Hipotesa Komparatif Kategorik Tidak Berpasangan Tabel 2xK) (Azwar, 2003)

\section{HASIL PENELITIAN}

Berdasarkan tabel 1 di bawah, terlihat bahwa persentase mahasiswa laki-laki FK-UNMAL angkatan 2014 yang melakukan aktivitas berolahraga (sebesar 59,1\%) lebih besar jika dibandingkan dengan yang tidak melakukan olahraga $(40,9 \%)$.

Tabel 1. Distribusi Frekuensi Berdasarkan Aktivitas Berolahraga

\begin{tabular}{lcc}
\hline Aktivitas & \multicolumn{2}{c}{ Jumlah Mahasiswa } \\
\cline { 2 - 3 } & $\mathbf{N}$ & $\mathbf{\%}$ \\
\cline { 2 - 3 } Berolahraga & 52 & 59.1 \\
\cline { 2 - 3 } $\begin{array}{l}\text { Tidak } \\
\text { Berolahraga }\end{array}$ & 36 & 40.9 \\
\hline Jumlah & 88 & 100 \\
\hline
\end{tabular}

Berdasarkan tabel 2 di dibawah, didapatkan hasil 59,1\% mahasiswa laki-laki FK-UNMAL Angkatan 2014 memiliki tingkat toleransi stres yang tinggi, 31,8\% memiliki tingkat toleransi stres yang sedang, sementara sisanya memiliki tingkat toleransi stres yang rendah $(9,1 \%)$.

Tabel 2. Distribusi Frekuensi Berdasarkan Tingkat Toleransi Stres

\begin{tabular}{lcc}
\hline Tingkat Toleransi Stres & \multicolumn{2}{c}{ Jumlah Mahasiswa } \\
\cline { 2 - 3 } Tinggi & $\mathbf{N}$ & $\mathbf{\%}$ \\
\cline { 2 - 3 } Sedang & 52 & 59.1 \\
\cline { 2 - 3 } Rendah & 28 & 31.8 \\
\hline Jumlah & 88 & 9.1 \\
\hline
\end{tabular}


Berdasarkan tabel 3 di atas, terlihat hasil uji statistik bivariate non-parametrik melalui Mann Whitney U Test didapatkan nilai probabilitas 0,000 . Oleh karena $0,000<0,05$ maka $\mathrm{H}_{0}$ ditolak yang berarti terdapat hubungan antara aktivitas berolahraga dengan toleransi stres pada mahasiswa lakilaki FK-UNMAL angkatan 2014. Selain itu, berdasarkan data analisis dari tabel di atas juga ditemukan semua mahasiswa laki-laki yang berolahraga memiliki toleransi stres yang tinggi sebesar 52 orang mahasiswa dengan presentase $100 \%$. Dengan demikian, dapat disimpulkan bahwa mahasiswa laki-laki yang tidak berolahraga memiliki resiko yang lebih besar terhadap toleransi stres yang sedang dan rendah.

Tabel 3. Hubungan Aktivitas Berolahraga dengan Toleransi Stres Mahasiswa Laki-laki Fakultas Kedokteran Universitas Malahayati

\begin{tabular}{|c|c|c|c|c|c|c|c|}
\hline & \multicolumn{6}{|c|}{ Tingkat Toleransi Stres } & \multirow[t]{3}{*}{$\mathbf{P}$} \\
\hline & \multicolumn{2}{|c|}{ Tinggi } & \multicolumn{2}{|c|}{ Sedang } & \multicolumn{2}{|c|}{ Rendah } & \\
\hline Kelompok & $\mathrm{N}$ & $\%$ & $\mathrm{~N}$ & $\%$ & $\mathrm{~N}$ & $\%$ & \\
\hline Berolahraga & 52 & 100 & 0 & 0 & 0 & 0 & \multirow{2}{*}{0,000} \\
\hline $\begin{array}{l}\text { Tidak } \\
\text { Berolahraga }\end{array}$ & 0 & 0 & 28 & 77.8 & 8 & 22.2 & \\
\hline Jumlah & 52 & 59.1 & 28 & 31.8 & 8 & 9.1 & \\
\hline
\end{tabular}

\section{DISKUSI}

Berdasarkan hasil penelitian diketahui bahwa dari 88 mahasiswa yang melakukan aktivitas berolahraga berjumlah 52 mahasiswa $(59,1 \%)$, dan berdasarkan hasil analisis bivariat didapatkan bahwa 52 mahasiswa yang berolahraga memiliki toleransi stres yang tinggi sebesar 100\% dan 36 mahasiswa yang tidak berolahraga memiliki toleransi stres yang sedang sebesar $77,8 \%$ dan toleransi stres yang rendah sebesar $22,2 \%$. Ini berarti olahraga yang dilakukan dapat mengatasi atau menurunkan stres psikologis yang dihadapi sehingga respon adaptasi terhadap stres menjadi lebih baik (Raglin \& Wilson, 2007).

Orang yang berolahraga memiliki toleransi stres yang tinggi, hal ini disebabkan karena pada orang yang berolahraga kadar BDNF (Brain-derived neurothropic factor) dan Beta-Endorphinsnya meningkat. BDNF berperan dalam meningkatkan kadar Long Term Potential (LTP) yang mendukung 
terjadinya plastisitas saraf sehingga meningkatkan fungsi memori dan pembelajaran yang pada akhirnya menyebabkan peningkatan toleransi terhadap stres (Young, 2007). Beta endorphins berperan dalam menurunkan kadar kortisol yang tinggi sehingga dapat menyebabkan kadar kortisol menjadi normal kembali. Kadar kortisol yang normal mengembalikan fungsi CRHR2 sehingga dapat meningkatkan fungsi emosi dan kognisi individu, fungsi kognisi dan emosi yang membaik dapat menyebabkan peningkatan toleransi stres individu (Zhao dkk, 2013).

Pada kondisi stres kronis, terjadi peningkatan kortisol yang berlebih didalam tubuh dan terjadi penurunan kadar BDNF di hipokampus (regio CA1 dan CA3) dan amigdala. Kadar kortisol yang berlebih tersebut menurukan respon CRHR2, sedangkan penurunan kadar BDNF menyebabkan menurunnya fungsi plastisitas. Penurunan respon CRHR2 dan kadar beta endorfins tersebut menyebabkan penurunan toleransi terhadap stres. Oleh sebab itu dengan berolahraga, individu dapat meningkatkan toleransi stresnya dan pada akhirnya mampu terhindar dari keadaan distres (Zhao dkk, 2013).

Penelitian-penelitian terdahulu membukti-kan bahwa BDNF memiliki pengaruh yang signifikan terhadap peningkatan toleransi stres, sebagaimana yang di lakukan oleh Cotman dan Berchtold (2002) menyebutkan bahwa pada bagian hipokampus yang dipaparkan sinar densitas tinggi menyebutkan bahwa terjadi peningkatan kadar BDNF yang lebih tinggi pada tikus yang diberikan perlakuan olahraga dibandingkan yang tidak diberikan perlakuan olahraga (Cotman \& Berchtold, 2002). Pada penelitian lainya oleh Vaynman dkk (2004) juga menyebutkan bahwa BDNF berpengaruh terhadap peningkatan toleransi stres melalui respon memori dan pembelajaran yang lebih baik pada tikus, pada tikus yang diberikan perlakuan olahraga 2 minggu, secara signifikn memiliki fungsi pembelajaran dan recall yang lebih baik dalam menemukan lokasi sebelumya daripada yang tidak diberikan perlakuan. Selain itu pada penelitian sebelumnya juga telah disebutkan peran Beta-Endorphins yang sangat penting meningkatkan toleransi stres, yang dilakukan pada kelompok tikus yang diberikan 
perlakuan olahraga, setelah 2 jam menunjukan tikus yang berolahraga kadar Beta-Endorphinsnya tinggi dan kortisol yang berlebih menjadi baik untuk merespon terhadap stres (Zhao dkk, 2013).

Pada penelitian Schmolesky dkk (2013) juga menyatakan bahwa peningkatan kadar BDNF pada orang yang berolahraga sangat aktif yaitu terjadi peningkatan kadar BDNF sebesar $45 \%$, sedangkan individu yang jarang berolahraga terjadi penurunan kadar BDNF sebesar 13\%. Oleh karena itu peneliti menganggap penelitian ini sesuai dengan penelitian sebelumnya yang menyatakan bahwa olahraga dapat meningkatkan kadar BDNF dan Beta Endorphins sehingga membantu dalam toleransi terhadap keadaan stres yang terjadi.

\section{KESIMPULAN DAN SARAN}

Berdasarkan hasil penelitian dapat disimpulkan bahwa terdapat hubungan antara aktivitas berolahraga dengan toleransi terhadap stres pada mahasiswa laki-laki FK-UNMAL angkatan 2014. Seluruh responden mahasiswa laki-laki yang melakukan aktivitas olahraga memiliki toleransi terhadap stres yang tergolong tinggi, sementara responden mahasiswa yang tidak berolahraga memiliki kemungkinan lebih besar untuk memiliki toleransi yang lebih rendah. Dapat diartikan bahwa olahraga dapat dijadikan cara untuk mengatasi atau menurunkan stres psikologis yang dihadapi sehingga respon adaptasi terhadap stres menjadi lebih baik. Dengan hasil penelitian ini, diharapkan masyarakat dapat lebih memperhatikan kesehatan mental masing-masing dan mampu menghadapi keadaan stres yang dialami dengan melakukan kebiasaan berolahraga. Institusi pendidikan, seperti Universitas Malahayati, juga diharapkan dapat mengkoordinasi kegiatan olahraga sebagai salah satu kegiatan rutin di kampus dengan harapan dapat meningkatkan toleransi terhadap stres pada mahasiswa laki-laki, terutama dalam situasi pendidikan.

Perlu dilakukan pengambilan sampel pada responden yang lebih banyak dan lebih luas sehingga dapat mengetahui keadaan toleransi stres secara menyeluruh, serta lebih diteliti pada jenis dan bentuk 
aktivitas berolahraga dan juga perlu di lakukan penelitian yang lebih spesifik dan mendalam dengan metode dan desain yang berbeda.

\section{DAFTAR PUSTAKA}

Azwar, A., \& Prihartono, J. (2003). Metodologi penelitian kedokteran dan kesehatan masyarakat. Batam: Binarupa Akara.

Christyanti, D., Mustami'ah, D., \& Sulistiani, W. (2012). Hubungan antara penyesuaian diri terhadap tuntutan akademik dengan kecenderungan stres pada mahasiswa Fakultas Kedokteran Universitas Hang Tuah Surabaya. Jurnal Insan Media Psikologi, 12(3).

Cotman, C. W., \& Berchtold, N. C. (2002). Exercise: a behavioral intervention to enhance brain health and plasticity. Trends in neurosciences, 25(6), 295-301.

Gould, D., \& Weinberg, R. S. (2003). Foundations of sport and exercise psychology. Human Kinetics.

Hassmen, P., Koivula, N., \& Uutela, A. (2000). Physical exercise and psychological well-being: a population study in Finland. Preventive medicine, 30(1), 17-25.

Johnson, J. H., \& Sarason, I. G. (1978). Life stres, depression and anxiety: Internal-external control as a moderator variable. Journal of psychosomatic research, 22(3), 205-208.

Klaperski, S., Seelig, H., \& Fuchs, R. (2012). Physical activity as a stres buffer. ZEITSCHRIFT FUR SPORTPSYCHOLOGIE, 19(2), 80-90.

Leahy, C. M., Peterson, R. F., Wilson, I. G., Newbury, J. W., Tonkin, A. L., \& Turnbull, D. (2010). Distres levels and self-reported treatment rates for medicine, law, psychology and mechanical engineering tertiary students: cross-sectional study. Australian \& New Zealand Journal of Psychiatry, 44(7), 608-615.

Li, X. H., Chen, J. X., Yue, G. X., Liu, Y. Y., Zhao, X., Guo, X. L., ... \& Bai, M. H. (2013). Gene expression profile of the hippocampus of rats subjected to chronic immobilization stres. PLoS One, 8(3), e57621.

Raglin, J. S., Wilson, G. S., \& Galper, D. (2007). Exercise and its effects on mental health. Physical activity and health, 1, 247-257.

Robbins, S. P. (2001). Organization Theory: Structure, Design and Applications,(Terjemahan Hadyana Pujaatmaka, Benyamin Molan. 2006).

Schmolesky, M. T., Webb, D. L., \& Hansen, R. A. (2013). The effects of aerobic exercise intensity and duration on levels of brain-derived neurotrophic factor in healthy men. Journal of sports science \& medicine, 12(3), 502.

Semiun, Y. (2006). Kesehatan mental 2. Yogyakarta: Kanisius, 46.

Shah, M., Hasan, S., Malik, S., \& Sreeramareddy, C. T. (2010). Perceived stres, sources and severity of stres among medical undergraduates in a Pakistani medical school. BMC medical education, 10(1), 2.

Sherina, M. S., \& Kaneson, N. (2003). The prevalence of depression among medical students. Malaysian Journal of Psychiatry, 11(1), 12-17.

Vaynman, S., Ying, Z., \& Gomez-Pinilla, F. (2004). Hippocampal BDNF mediates the efficacy of exercise on synaptic plasticity and cognition. European Journal of Neuroscience, 20(10), 2580-2590.

Young, S. N. (2007). How to increase serotonin in the human brain without drugs. Journal of psychiatry \& neuroscience: JPN, 32(6), 394 